\title{
Distribution and morphology of the surface ruptures of the 2018 Donggala-Palu earthquake, Central Sulawesi, Indonesia
}

\author{
Asri Jaya $^{1^{*}} \mathbb{D}$, Osamu Nishikawa ${ }^{2}$ and Sahabuddin Jumadil ${ }^{1}$
}

\begin{abstract}
A large Mw 7.5 earthquake occurred at 18.03 on 28 September 2018 in the Donggala-Palu area of Central Sulawesi, Indonesia, which triggered a tsunami, liquefaction, and landslides. A 160-km rupture zone was formed on the surface along the NS to NNW-SSE trending Palu-Koro fault (PKF) system through three regencies: Donggala, Palu, and Sigi. Obvious surface ruptures associated with the earthquake were not observed in the epicentral area. Surface ruptures with a small displacement of both sinistral and westerly downward slip components appear south of the epicentral area in the Donggala area. The event induced widespread subsidence of the Donggala coastal area on the west side of the rupture zone. Passing across the Palu bay, the rupture cuts through the urban area of Palu city and extends across alluvial fans along the western side of the Palu basin showing large displacements with a predominant sinistral slip up to $4.2 \mathrm{~m}$ and subordinate easterly downward slip components. Approximately $5 \mathrm{~m}$ of anomalously high vertical displacement with $3 \mathrm{~m}$ of horizontal displacement occurs in an extensional bend in the southern area of the Palu basin. In the Sigi valley, the rupture zone follows the previously known PKF trace showing predominant sinistral and subordinate easterly downward slip, of which displacement is $0.9 \mathrm{~m}$ sinistral and $0.5 \mathrm{~m}$ easterly downward at the site $60 \mathrm{~km}$ south of Palu city and gradually smaller toward the south. These distributions of rupture zones and displacements suggest that rupture of the 2018 earthquake unilaterally propagated southwards and resulted in the movement of the eastern side of the fault towards the NNW.
\end{abstract}

Keywords: Palu-Koro fault, 2018 Donggala-Palu earthquake, Displacement, Surface rupture, Subsidence, Liquefaction

\section{Introduction}

An Mw 7.5 earthquake occurred in the Donggala-Palu area of Central Sulawesi, Indonesia at 18.03 on 28 September 2018 (hereafter referred to as the 2018 earthquake). The main shock focus is estimated approximately $80 \mathrm{~km}$ north of Palu city (Figs. 1,$2 ; 0.2559^{\circ} \mathrm{S}-119.8462^{\circ} \mathrm{E}$ ) and $20 \mathrm{~km}$ deep (USGS 2018; Fig. 6). Several minutes later, it was followed by a tsunami around Palu bay, significant liquefactions and hundreds of landslides. This earthquake caused heavy causalities and severe damages

\footnotetext{
*Correspondence: asrijaya@unhas.ac.id; asri_jaya@geologist.com ${ }^{1}$ Department of Geological Engineering, Hasanuddin University, J. Poros Malino KM.6 Bontomarannu, Gowa, South Sulawesi 92171, Indonesia Full list of author information is available at the end of the article
}

to houses and infrastructures in this region, especially in the communities around the rupture zones in the Donggala, Palu, and Sigi regencies, which the Palu-Koro fault system runs through.

The Palu-Koro fault (PKF) is known as one of the major regional active fault systems in the Sulawesi area, consisting of a series of strike-slip faults that generally trends N-S and NNW-SSE (Bellier et al. 2001, 2006; Socquet et al. 2006; Fig. 1). The PKF has been considered a significant source of the regional seismic hazard in Central Sulawesi due to a long fault trace over $200 \mathrm{~km}$ (Bellier et al. 2006; Watkinson and Hall 2017), and frequent occurrences of large and moderate earthquakes (Mw 6-7.6) (Pelinovsky et al. 1997; Go'mez et al. 2000; 
(See figure on next page.)

Fig. 1 Map showing the distribution of ruptures, ground fissures, hot springs, subsidence areas, liquefaction zones, and landslides associated with the earthquake that occurred on 28 September 2018 in the Donggala-Palu area of Central Sulawesi, Indonesia. Structural lineaments are modified after Watkinson and Hall (2017). The base map is a 30 m DEM-SRTM (USGS). Original data to make distribution of surface rupture Fig. 1 are compiled in Additional file 1

Prasetya et al. 2001). Based on this information, a probabilistic model for seismic hazard in Sulawesi has been proposed (Cipta et al. 2017). However, records of this seismicity have been limited to minimal information on the year of occurrence, epicentre, and magnitude, and mostly contain vague information. Furthermore, the positions of the seismic sources are generally offshore the Makassar Strait except for the event in 1938 (Mw 7.6) and a few Mw 6 class events in the southern part of the PKF. Therefore, PKF lacks fundamental information for seismic hazard assessment.

It is essentially important for the prevention of future disasters to clarify the characteristics of rupture associated with the activity of the PKF that involves extent, distribution, displacement, and sense of shear. Surface ruptures of the 2018 earthquake were exposed in a large area along with the PKF system. It is crucial to record field data of surface ruptures immediately after the event since they rapidly disappear due to human activities and erosion by rainfall. In this paper, we report the preliminary results of a field survey on distribution, orientation, displacement, and slip sense of the ruptures associated with the 2018 earthquake, which was conducted mostly within 7 weeks of the event.

\section{Outline of the Palu-Koro fault system}

The PKF is a major strike-slip fault cutting through the central part of Sulawesi Island (Fig. 1), extends close to northern tip of the Matano Fault to the south and western part of the Celebes Sea to the north, where the North Sulawesi subduction zone is located (e.g., Hamilton 1979; Bellier et al. 2006; Socquet et al. 2006). The seismicity and tectonics of the Central Sulawesi fault system (CSFS), which consists of the PKF, Matano fault, Poso fault, Lawanopo fault and Kolaka fault have been reported by numerous researchers (e.g., Tjia 1981; Hamilton 1979; Silver et al. 1983; Bellier et al. 2001, 2006; Watkinson and Hall 2017). The activity of the CSFS is associated with the westward motion of the Sula platform, which causes the sinistral displacements along the faults and intensive seismicity within the region. Slip rate of the PKF has been estimated at $35 \pm 8 \mathrm{~mm}_{\text {year }}{ }^{-1}$ using GPS, which is similar to the long-term slip rate estimated from geomorphological investigations (e.g., Silver et al. 1983; Walpersdorf et al. 1998a, b; Bellier et al. 2001, 2006; Socquet et al. 2006).
The epicentre of the mainshock of the 2018 earthquake is located $80 \mathrm{~km}$ north of Palu city $\left(0.2559^{\circ} \mathrm{S}-119.8462^{\circ} \mathrm{E}\right)$. The rupture zone can be divided into two parts depending on general trend; the northern $80 \mathrm{~km}$ running through the Donggala regency from the epicentre to the Palu bay is N-S trending, while the southern part which passes through the Palu basin and Sigi valley shows NNW-SSE trend (Fig. 2).

\section{Methods}

We conducted a field survey within 7 weeks of the mainshock of the 2018 earthquake (9-12 October and 6-17 November) and mapped associated surface ruptures for a distance over $200 \mathrm{~km}$, in the area from $10 \mathrm{~km}$ north of epicentre to $80 \mathrm{~km}$ south of Palu city. A field survey was conducted along the roads and rivers crossing the area with intense deformation of ground surface and damage of constructions. Since the rupture area is quite extensive, we have used some remote sensing data such as InSAR data produced soon after the earthquake (e.g., GSI 2018) and information from the local community as guidance to identify the trace of coseismic ruptures, especially in the northern and southern parts of the survey area. To ensure the relationship between rupture distribution and geomorphological features, we used the Digital Elevation Model (DEM) based on Shuttle Radar Topography Mission (SRTM) 1 arc second global $30 \mathrm{~m}$ resolution (https ://earthexplorer.usgs.gov/), data processing used Global Mapper software. We also used satellite imagery from Google Earth (updated 2016 and 2018) for certain areas. All images dataset were integrated into ArcGIS.

We adopted criteria for judgment if fractures of ground surface are surface ruptures associated with the 2018 earthquake that have: (1) lateral continuity, (2) displacements that show a common slip sense in each site, and (3) fresh appearance without erosion that indicate coseismic. Other coseismic fractures are referred to as ground fissure in this paper. We measured orientation data of fractures (strike and dip of fracture planes, and the rake of slickenline on the plane), lateral (strike-slip) and vertical displacements, slip sense and width of the rupture zone defined as the range in which ground is flexurally deformed using reference markers (e.g., roads, channels, and walls) by conventional instruments for field survey such as a hand-held GPS receiver, clinometer, tape measure, and hand level. 


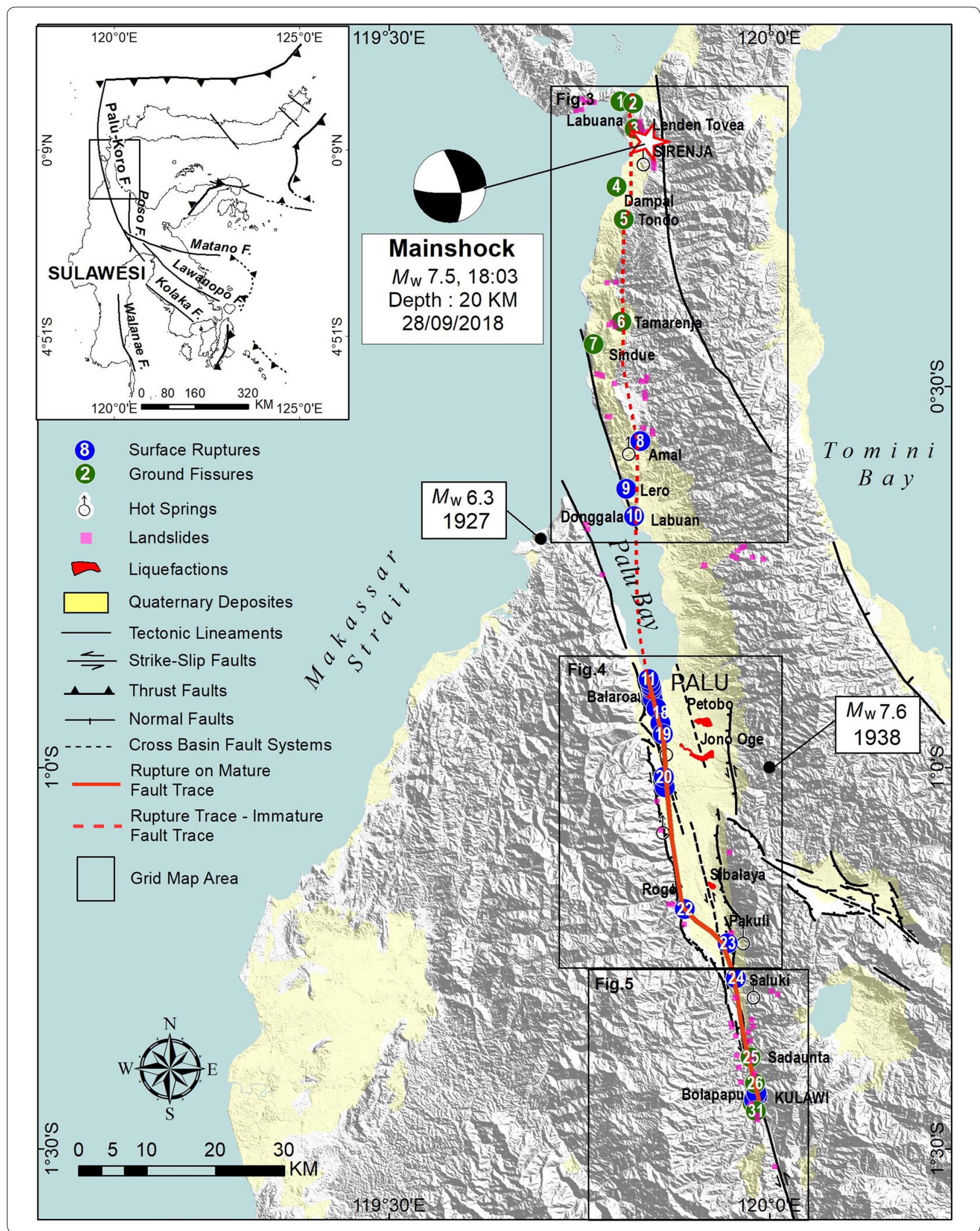




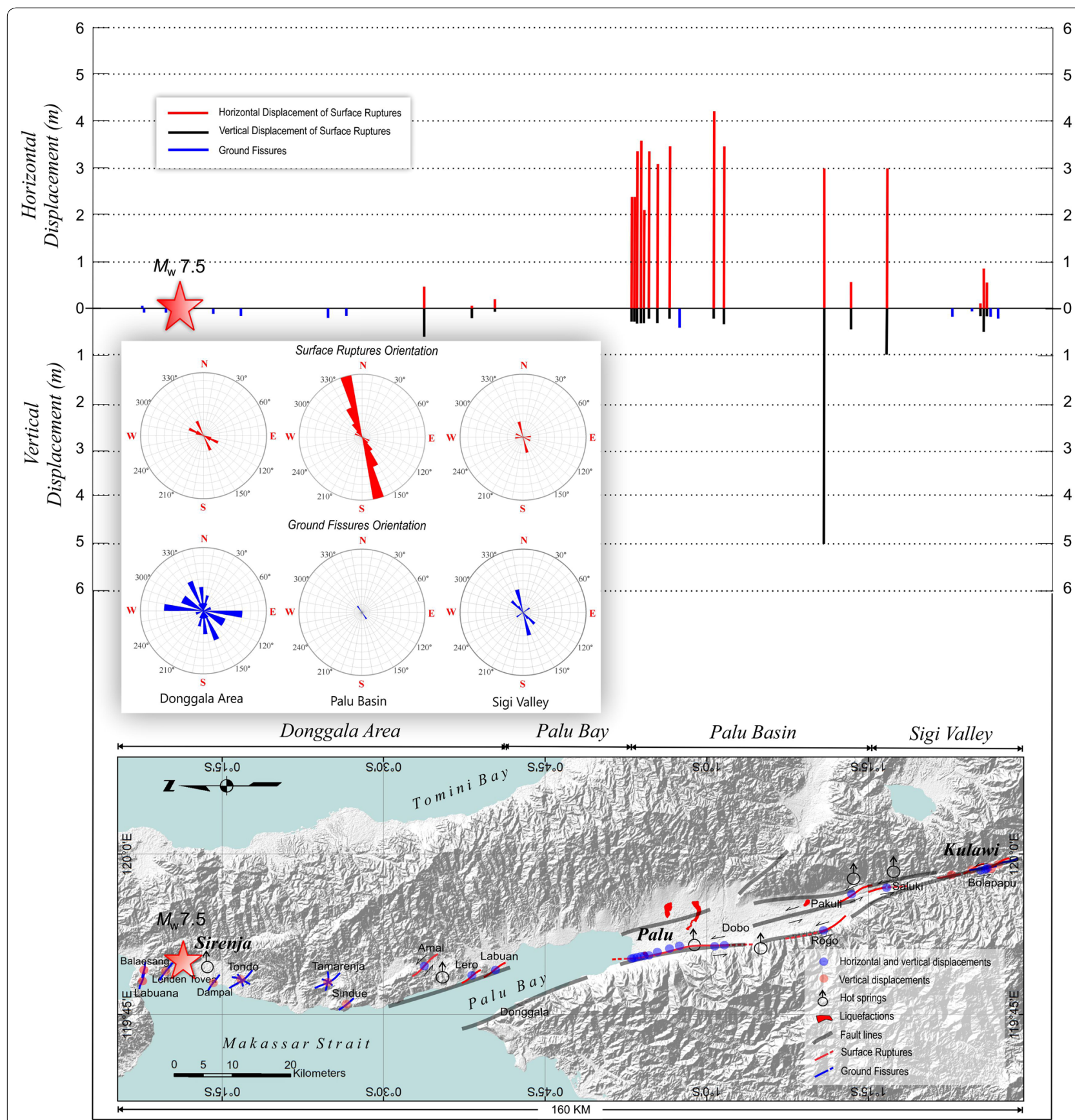

Fig. 2 Displacements of surface ruptures measured in the field. a Horizontal and vertical displacement along the surface rupture zone. Black column: surface rupture, grey column: ground fissures that are not confirmed as surface rupture. $\mathbf{b}$ Distribution of surface rupture formed by the 2018 earthquake (red line), ground fissure (blue line), and tectonic lineament of presumed fault (grey line). The length of ruptures and ground fissures showed on the map are exaggerated. The base map is a $30 \mathrm{~m}$ DEM-SRTM (USGS). Rose diagrams of fracture orientations are also shown. Original data to make distribution of surface rupture in Fig. 2 are compiled in Additional file 1

\section{Results}

\section{The northern (Donggala) area}

In the northern (Donggala) area, the rupture zone associated with the 2018 earthquake does not coincide with any previously inferred fault trace, but runs through a coastal plain and small inland basin chain, contrasting with the southern parts (Palu basin and Sigi valley) where new surface breaks follow the clear fault trace of PKF. Since significant damages were reported mostly to the south of the epicentre, observations have not been made further 
north of the region approximately $10 \mathrm{~km}$ north of epicentre $\left(0.1258^{\circ} \mathrm{S}-119.8043^{\circ} \mathrm{E}\right)$ in our survey.

Around the epicentre and to the north, serious damages such as intense ground fissures, rock falls, landslides, destruction of houses and discharges of high-temperature hot springs that infer deep-reaching fractures, are distributed along an approximate $\mathrm{N}-\mathrm{S}$ direction (Fig. 3f). In Dampal village close to the epicentre (Table 1), numbers of discontinuous and short ground fissures which orient NW-SE were observed in a dried coastal marsh. They accompany sand eruption indicating liquefaction (Fig. 3f). In the areas $8 \mathrm{~km}$ and $20 \mathrm{~km}$ south of epicentre (Tondo and Tamarenja villages; Figs. 1, 2, Table 1), ground fissures trending from NW-SE to NE-SW are formed concentrated in the zone of several tens of metres, respectively. However, in our surveys crossing the area where crustal movement is inferred from remote sensing images (e.g., GSI 2018), distinct surface ruptures were not observed.

A few displacement measurements were made for ruptures in several sites south of the epicentral area. In Amal village, approximately $40 \mathrm{~km}$ south of the epicentre, a clear NW-SE trending surface rupture zone is exposed linearly over $900 \mathrm{~m}$ in length (Figs. 1, 2, 3g; Table 1). At the site it crosses a road and a water channel, the main rupture almost vertical and striking about $300^{\circ}$ shows sinistral and westerly downward slip with $0.4 \mathrm{~m}$ horizontal and $0.7 \mathrm{~m}$ vertical displacements in the flexural deformed zone of $3.2 \mathrm{~m}$ wide (Figs. 2, 3g; Table 1). In Lero and Labuan villages in the southern coastal area of Donggala area, NNW-SSE striking ruptures are exposed, both are single fractures and show almost vertical or steep dip and small offsets less than $20 \mathrm{~cm}$ in both horizontal and vertical displacements (Figs. 1, 2, 3i; Table 1). Observed horizontal slip senses are inconsistent with each other.

Coastal areas on the west side of the rupture zone are widely subsided. Although detailed mapping of subsidence has not yet been performed through the region, coasts near the epicentre (Sirenja coast) and the south end of the rupture zone in the Donggala area (Lero coast) show particular significance, where a transgression of coastline and a widespread flooding at high tide have occurred resulting from subsidence as much as $3 \mathrm{~m}$ since the 2018 earthquake (Fig. 3c, h).

\section{The southern area \\ The Palu basin}

A rupture zone cut through the western part of the Palu basin trending NNW-SSE (Fig. 2). Although the clear geomorphological feature suggesting a recent fault activity is recognised by straight mountain fronts and triangular facets in the western side of the basin, the new rupture zone does not follow it and runs several hundreds of metres east of mountain base across the alluvial fans. Even though the distance from the epicentre is over $80 \mathrm{~km}$, the horizontal displacement of rupture is largest around Palu city (Figs. 1, 2). We observed ruptures crossing the urban area (Fig. 4). A narrow zone with intense destruction and abrupt bending of the road is continuous for several kilometres southwards. The rupture zone is formed approximately 2.9 to $16.0 \mathrm{~m}$ wide and shows common sinistral and easterly downward slip sense. Horizontal and vertical components of slip range from 2.1 to $4.2 \mathrm{~m}$ and from 0.2 to $0.35 \mathrm{~m}$, respectively (Figs. 1, 2, 4b, d; Table 1).

There is a bend section where rupture zone obliquely traverses across the southern part of the Palu basin, along a fault trace the red surface rupture trace that links Rogo with Saluki known as the Saluki fault trending NW-SE (Figs. 1, 2; PuSGeN 2017). We refer to this section as Rogo bend. At the west end of the Rogo bend, a steeply dipping rupture with anomalously high vertical displacement of $5 \mathrm{~m}$ and horizontal displacement of $3 \mathrm{~m}$ is observed (Fig. 4f). Net displacement is estimated approximately $5.8 \mathrm{~m}$ assuming vertical rupture plane. In the Rogo bend, ruptures show relatively large vertical displacement (Table 1).

One of the striking phenomena of the 2018 earthquake is intense liquefaction with mudflow. In the Palu basin, at least four huge liquefactions with mudflows occurred: Balaroa area $\left(370,000 \mathrm{~m}^{2}\right)$ in the west side of the rupture zone, Petobo $\left(1,539,000 \mathrm{~m}^{2}\right)$, Jono Oge $\left(1,690,000 \mathrm{~m}^{2}\right)$ and Sibalaya $\left(1,000,000 \mathrm{~m}^{2}\right)$ on the east side. Liquefaction areas are located on gently inclined slopes 2-60 m high at the foot of high mountains, where there are old alluvial fans with a very shallow water table (Fig. 1). Surface water of irrigation systems and topographic slopes $\geq 1.5^{\circ}$ have been suspected to have induced the liquefaction with landslide in eastern Palu Valley (e.g., Bradley et al. 2019; Watkinson and Hall 2019). Therefore, sides of the basin where thick alluvial fan materials cover are hazard areas of large-scale liquefaction.

\section{The Sigi valley}

This area is located south of the Palu basin, and the trace of the PKF is considered to pass along a narrow and straight valley. Fractures of the ground surface orient predominantly NNW-SSE and subordinately NW-SE. The rupture zone generally follows the trace of PKF showing sinistral and easterly downward slip sense. Both the maximum horizontal (3.0 m sinistral) and vertical $(1.0 \mathrm{~m}$ westerly downward) slips of rupture were observed on the western slope of a hill in the northernmost part of Sigi valley, a little south of Rogo bend (Figs. 1, 2, 5b; Table 1). However, data of vertical slip component in this site are not certain since there is a possibility that the western 

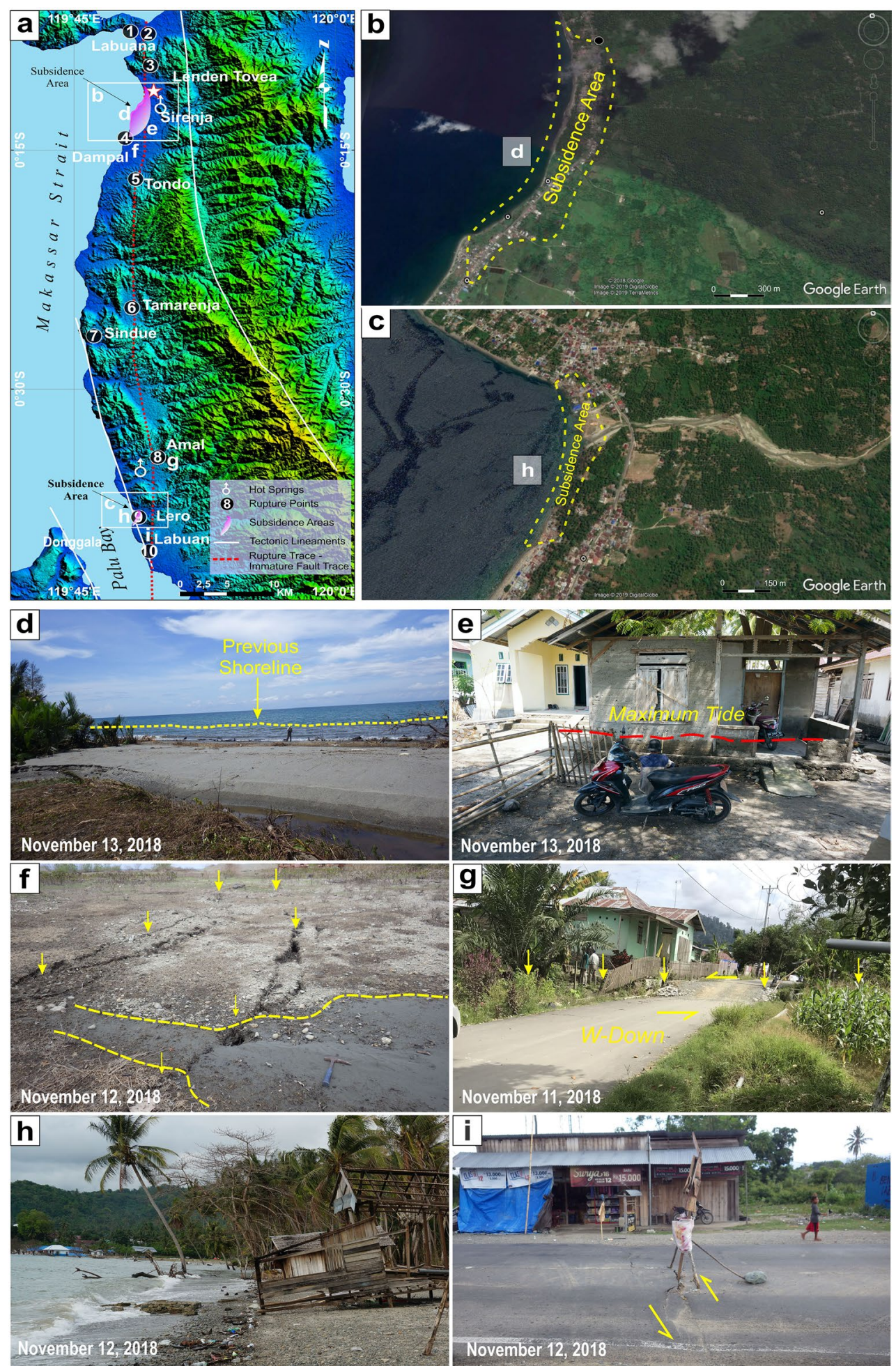

Fig. 3 a Site map of surface rupture, ground fissures, hot springs, and subsidence areas in the Donggala area. Structural lineaments are dawn after Watkinson and Hall (2017). The base map is a 30-m DEM-SRTM (USGS). b The subsidence area around Sirenja coastline (overlaid on Google Satellite imagery, darker updated from 2016 and lighter updated from 2018) and c Lero coastline (overlaid on Google Satellite imagery updated from 2018). d The shoreline retreated landward due to subsidence at Dampal-Lenden Tovea village. e Maximum tide as evidence of subsidence at Dampal-Lenden Tovea village. $\mathbf{f}$ Fissures and sand eruption at Dampal village. $\mathbf{g}$ A surface rupture cutting a road in Amal village. $\mathbf{h}$ The shoreline retreated landward and eroded houses and coastal forests due to subsidence at Lero village. i A displacement across the road at Labuan village 


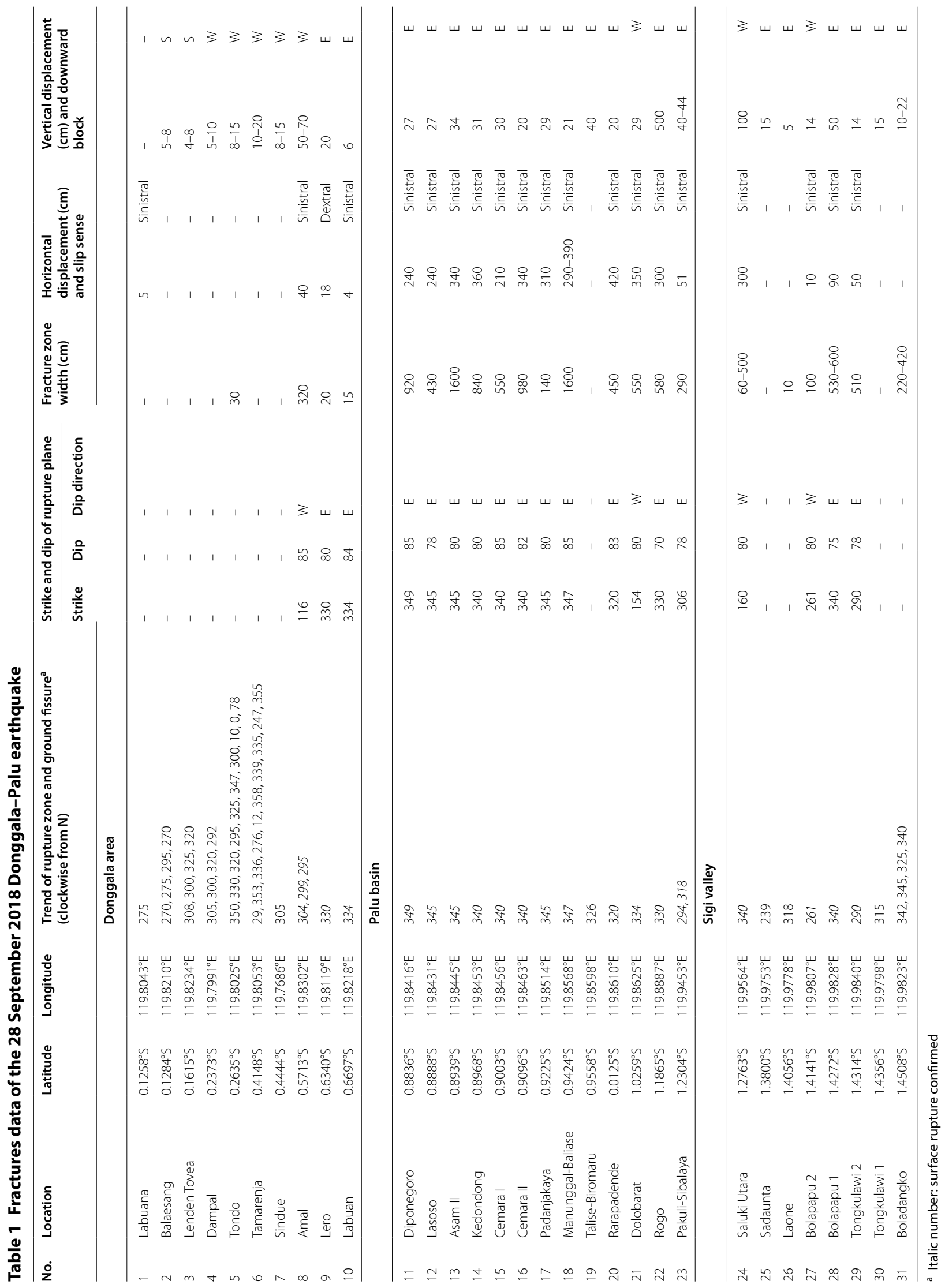



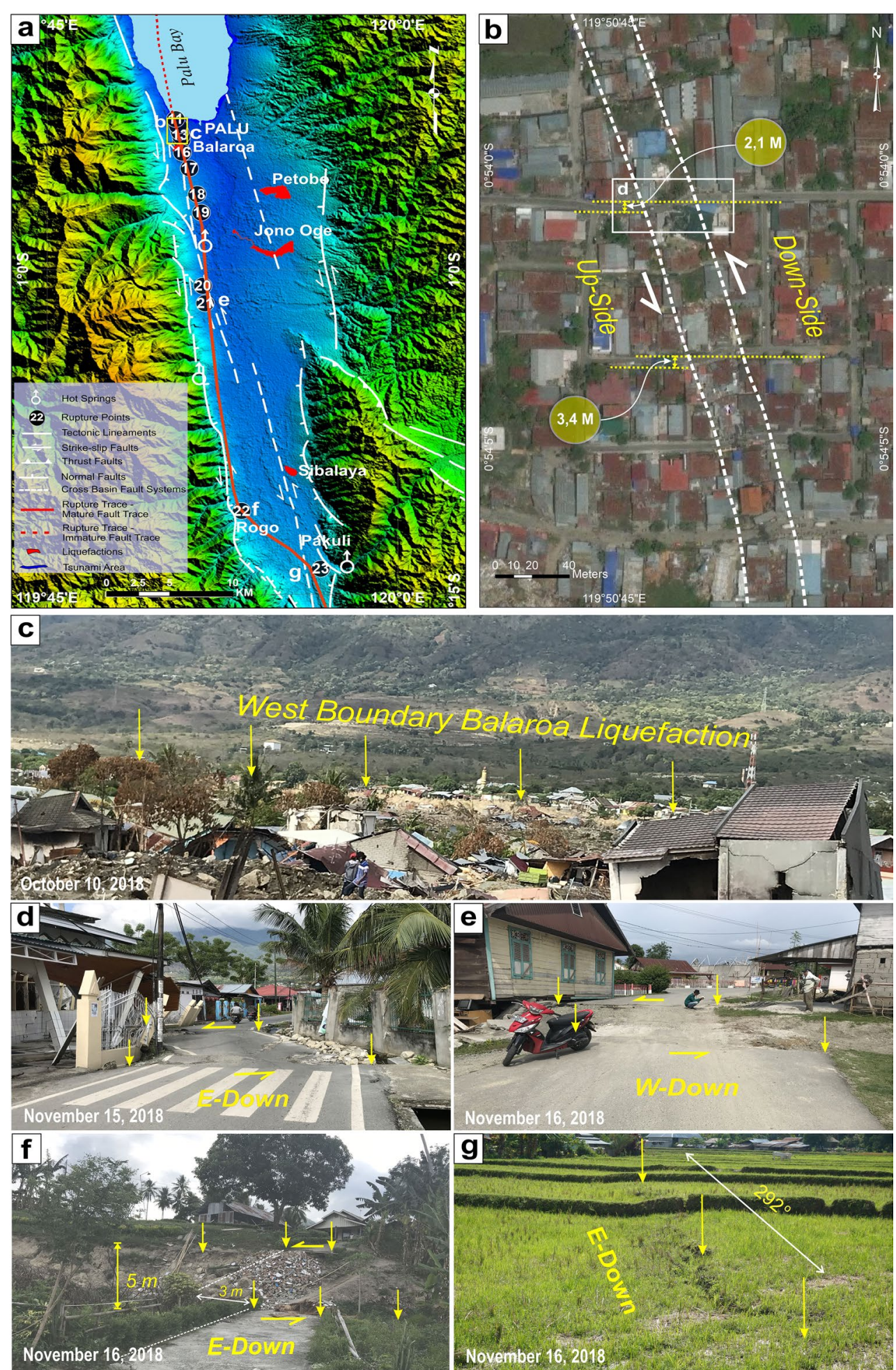

Fig. 4 a Site map of surface rupture, ground fissures, hot springs, and liquefaction areas in the Palu basin area. Structural lineaments are drawn after Watkinson and Hall (2017). The base map is a 30-m DEM-SRTM (USGS). b The rupture zone crossing the urban area of Palu city, in which constructions are seriously damaged. Abrupt bending of roads indicates a sinistral slip. (overlaid on Google Satellite imagery updated from 2018). c Liquefaction in the Balaroa area. d Surface rupture crossing Cemara I street in Palu city. e Surface rupture of Dolo Barat. f Surface rupture of Rogo village $(5 \mathrm{~m}) . \mathbf{g}$ Surface rupture extending in a rice field in Pakuli village 


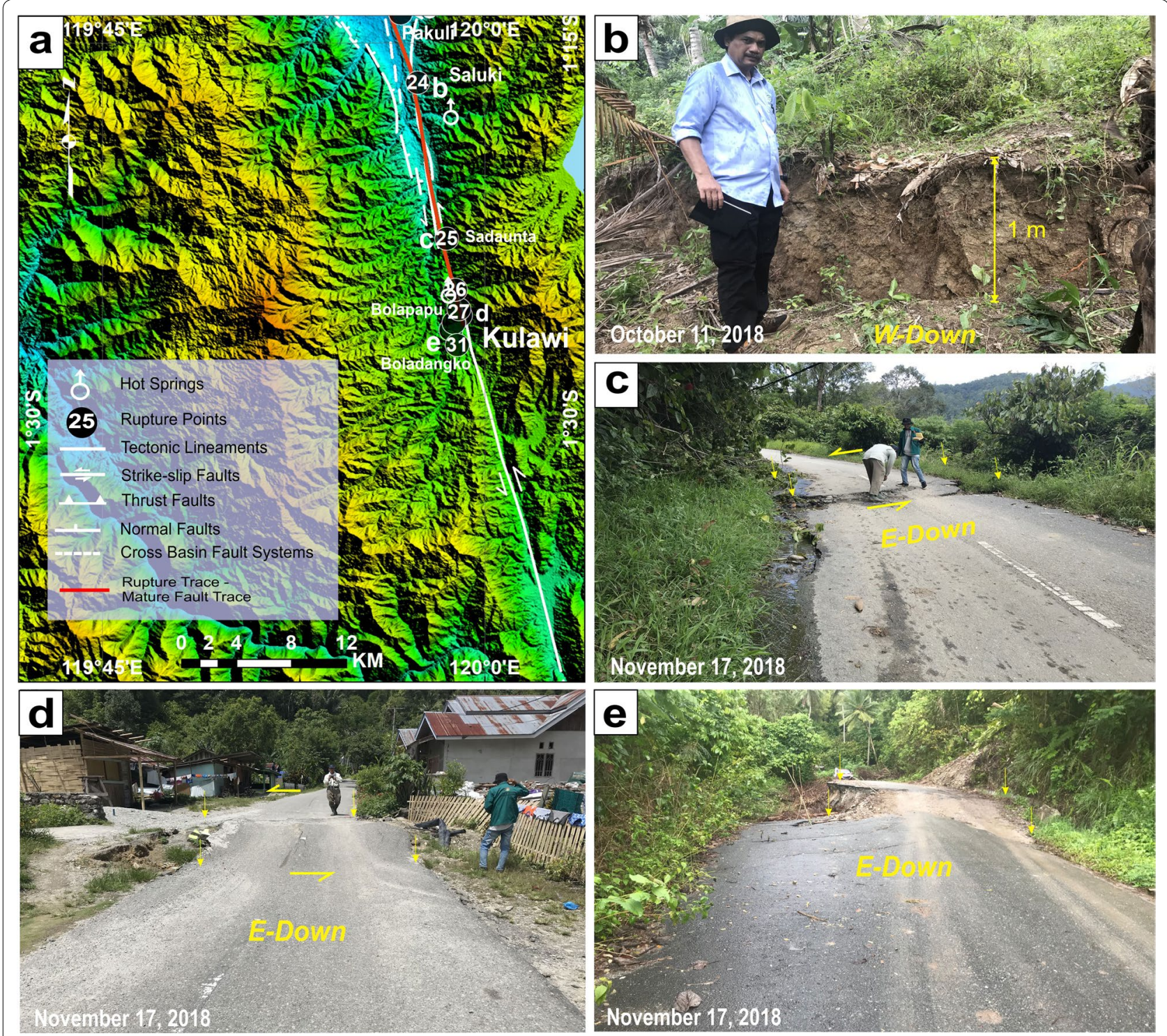

Fig. 5 a Site map of surface rupture, ground fissures, hot springs in the Sigi valley. Structural lineaments are drawn after Watkinson and Hall (2017). The base map is a $30 \mathrm{~m}$ DEM-SRTM (USGS). Surface rupture in b Saluki village, $\mathbf{c}$ Laone, d Bolapapu 1 village, and e Boladangko village

ground surface on the slope side fell down along the fracture. In the Bolapapu 1 villages $\left(1.4272^{\circ} \mathrm{S}-119.9828^{\circ} \mathrm{E}\right)$, $60 \mathrm{~km}$ south of Palu city, a surface rupture cuts roads and extends rice fields showing sinistral and easterly downward slip with $0.9 \mathrm{~m}$ horizontal and $0.5 \mathrm{~m}$ vertical displacements in a zone approximately $6 \mathrm{~m}$ in width (Figs. 1, 2, 5d; Table 1). In the area further south, clear surface ruptures were not found. Besides ground fissures, landslides, destruction of roads and houses are not so severe compared to the north. Although our field survey does not provide perfect data of rupture distribution due to bad road conditions to the south and lack of roads crossing the valley parallel to the PKF trace, these distribution patterns are almost consistent with InSAR and PGA maps published after the earthquake (GSI 2018; USGS 2018; Bao et al. 2019; Socquet et al. 2019; Zhang et al. 2019; GEER 2019).

\section{Discussion}

In the past 100 years, a number of moderate and large earthquakes ( $\leqq M w 7.7)$ have occurred in Central Sulawesi area (Pelinovsky et al. 1997; Go'mez et al. 2000; Prasetya et al. 2001, Fig. 6). However, the epicentres of these earthquakes are widely scattered over the regions, mostly distributed offshore or beyond the 2018 earthquake rupture zone. Previous studies predicted $\mathrm{Mw}$ 


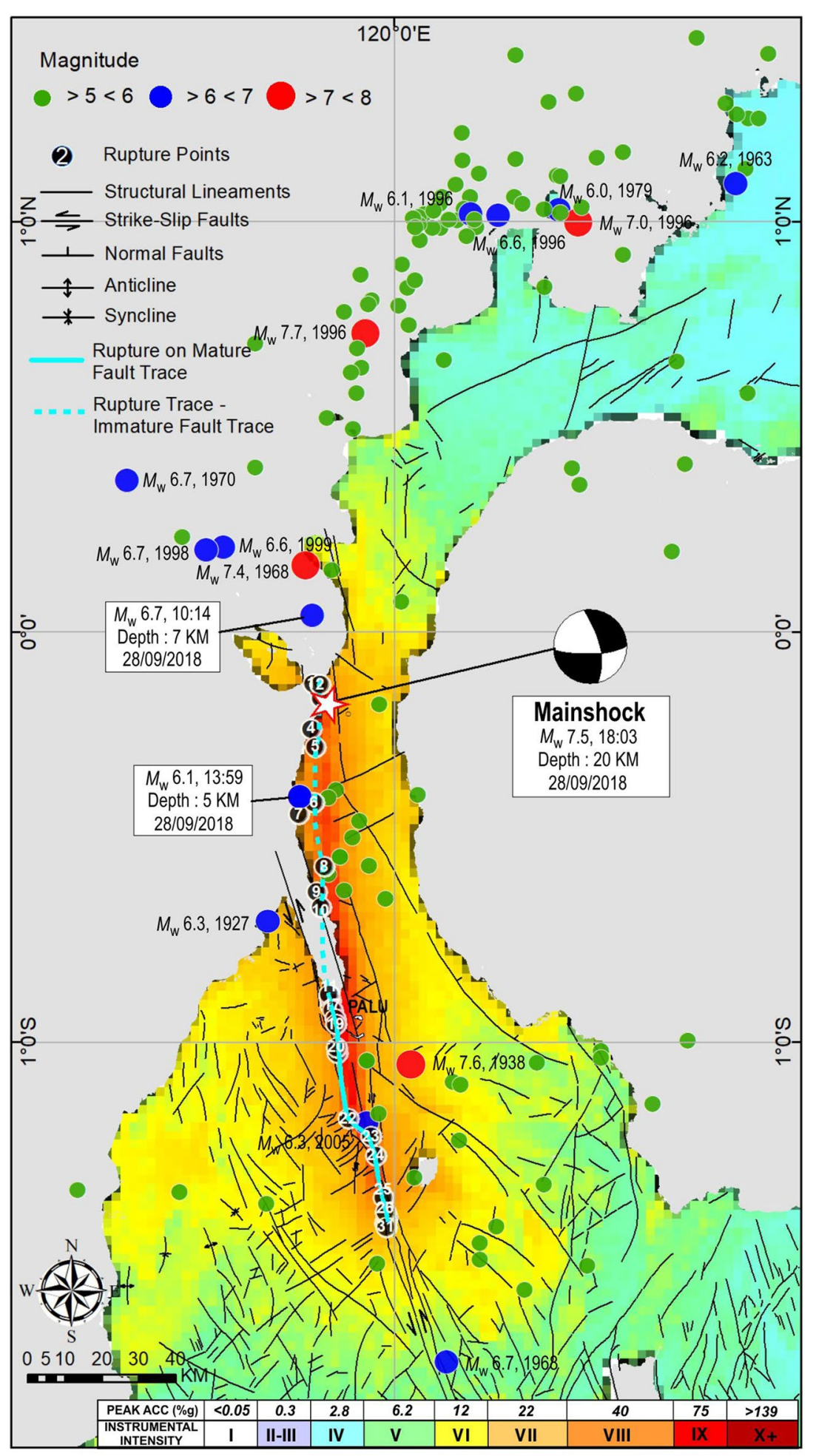

Fig. 6 Seismicity of Central Sulawesi area. Epicentres of moderate and large events (Mw 5-8) that occurred in shallow depth ( $<35$ km) from 1929 to 2019 are shown. Magnitude source: Pelinovsky et al. (1997); USGS, and Indonesian Earthquake Catalog, the based map: peak ground acceleration (PGA) by USGS (2018). Rupture trace inferred from radar satellite imagery is also shown as dashed line after Socquet et al. (2019). Structural lineaments are drawn after Ratman (1976), Sukamto (1973), Simandjuntak et al. (1991), Sukido et al. (1993), Watkinson (2011), Watkinson and Hall (2017) 
6.8-8.0 earthquakes to occur on the PKF with a recurrence interval less than 700 years based on paleoseismicity analysis (Bellier et al. 1998; Watkinson and Hall 2017). Therefore, the earthquake on 28 September 2018 most likely corresponds to the upper end of that range of potential earthquake scenarios yielding surface rupture as long as $160 \mathrm{~km}$ from the south of epicentre in the Donggala Regency to the Sigi Regency, and a maximum net displacement of approximately $5.8 \mathrm{~m}$ in the Rogo bend.

These field data were evaluated using the following empirical relationship between length and maximum displacement of exposed fault and moment magnitude scale (Mw) (Wells and Coppersmith 1994):

$$
\mathrm{Mw}=5.16+1.12 \log (L)
$$

and

$$
\mathrm{Mw}=6.81+0.78 \log (D),
$$

where $L$ and $D$ are fault length and maximum displacement, respectively. Based on Eqs. (1) and (2), $L$ and $D$ are estimated approximately $123 \mathrm{~km}$ and $7.7 \mathrm{~m}$, respectively, for Mw 7.5 which has been determined for the 2018 event (e.g., USGS 2018). The predicted length and the maximum displacement of rupture are much shorter and slightly larger than those obtained in our field survey, respectively. Therefore, 2018 Donggala-Palu earthquake is characterised by a long-distance rupture propagation.

Surface ruptures are exposed only south of the epicentre of the 2018 earthquake, indicating a unilateral propagation toward the south. It is also a distinct feature of this event that little displacement was observed in the epicentral area, while the largest displacement was measured around the Palu basin, which is $80 \mathrm{~km}$ from the epicentre. The southern part of the new rupture zone associated with the 2018 earthquake (Sigi valley and Palu basin) generally follows distinct tectonic lineaments of the PKF system trending NNW-SSE (Watkinson and Hall 2017). In contrast, the surface ruptures to the north deviate from the presumed path of the PKF, which passes along the west side of Palu bay and extends northward offshore, but cuts through the Donggala Regency in the North Arm, where there are few distinct geomorphic features. Although the rupture zone is inferred $\mathrm{N}-\mathrm{S}$ trending from the distribution of site of intense ground fissures, landslides, and hot springs as well as surface ruptures in the northern part, the continuous rupture zone cutting throughout the region is not clearly recognised since only a few sites of surface ruptures were confirmed due to their small displacements and NW-SE trends that may be oblique branches to the inferred main fault. These facts indicate that the northern part of the PKF system may be immature consisting of multiple faults diverged northward at the Palu basin or Palu bay. Another possibility is that the northern section of the earthquake did not originate on the PKF, but on a less mature fault system to the east of a mature PKF.

The surface rupture of the 2018 earthquake shows a consistent sinistral slip all over the area. In contrast, except for the Rogo bend, the vertical slip component is subordinate through the rupture zone and shows some variation of slip sense between the regions; the northern part shows westerly downward slip, while slip sense of the southern part is predominantly easterly downward (Table 1). Subsidence areas along the Donggala coast are on the west side of the rupture zone, consistent with the vertical slip sense of the northern rupture zone. The main rupture zone extends in a very narrow orientation range between $\mathrm{N}-\mathrm{S}$ (in the northern part) and NNW-SSE (in the southern part). Therefore, a subtle change of the rupture zone trend most likely controls slip sense of the vertical component. The relative motion of the east block of the rupture zone toward the direction slightly west from the north can account for this regional variation, and results in both contractional and extensional states in the northern and southern areas, respectively. A dominance of easterly downward slip in the NW-SE trending Rogo bend in the south end of the Palu basin indicates a progressive crustal transtension, which has most likely accommodated extension and subsidence of a narrow basin extending NNW by this block motion over a longer timescale.

The extent and displacement of the rupture zone observed in our field survey are generally consistent with interferometric images of crustal deformation created from ALOS-2/PALSAR-2 data (Fig. 6; GSI 2018; Socquet et al. 2019), and slip displacement distribution based on GSN broadband waveforms provided by the USGS (2018). Nevertheless, a further detailed investigation is necessary for the elucidation of a precise rupture distribution, morphology, and crustal deformation associated with the 2018 earthquake (Additional file 1).

\section{Conclusions}

The earthquake that occurred on 28 September 2018 in Central Sulawesi produced a $160-\mathrm{km}$-long surface rupture with a maximum net displacement of approximately $5.8 \mathrm{~m}$ and triggered a tsunami, liquefaction with mudflows and landslides. Surface ruptures with both sinistral and down-to-the-west extensional slip appear along the western coast of the Donggala area, south of the epicentre. A distinct rupture zone cuts through the urban area of Palu city and extends across alluvial fans along the western side of Palu basin, showing displacements with large sinistral and subordinate easterly downward slip components. The maximum vertical displacement appears in a transtensional bend in the southern area of 
the Palu basin. In the Sigi valley, the rupture zone follows the previously known PKF traces with sinistral and easterly downward slip components. The 2018 earthquakeinduced widespread subsidence of coastal areas west of the rupture zone in the northern part. These distributions of displacement, slip sense, and crustal deformation suggest that the motion direction of the east block of the rupture zone was slightly west from the north.

\section{Supplementary information}

Supplementary information accompanies this paper at https://doi. org/10.1186/s40623-019-1126-3.

Additional file 1. Locations of surface ruptures along the Donggala-Palu earthquake, where the name of the locality, latitude ( $\left.{ }^{\circ} \mathrm{S}\right)-$ Iongitude $\left({ }^{\circ} \mathrm{E}\right)$ coordinates of location, trend of rupture zone and ground fissure, strike and dip of rupture plane, the width of fracture zone, horizontal displacement $(\mathrm{cm})$ and slip sense direction of fracture, the vertical displacement $(\mathrm{cm})$ and direction of the downward block of fractures, respectively.

\section{Abbreviations}

PKF: Palu-Koro Fault; CSFS: Central Sulawesi fault system.

\section{Acknowledgements}

We are concerned for the people of Central Sulawesi and the victims of this earthquake. We express gratitude and appreciation to the Ministry of Higher Education of Indonesia and Hasanuddin University for providing a research grant. We thank Weiren Lin and lan M. Watkinson for helpful comments and advice. We also thank Sandy Tias Setiawan and the students of Tadulako University (Palu) for supporting us during the field survey.

\section{Authors' contributions \\ All the authors were involved in fieldwork that was conducted 7 and 40 days after the earthquake in two stages. SJ compiled photos, field data, and prepared the dataset. AJ analysed data, drew maps and figures, prepared and edited the draft of manuscripts. ON edited and reviewed all part of the manu- scripts. All authors read and approved the final manuscript.}

\section{Funding}

This research was funded by International Research Collaboration (PKLNNo.6125/UN.4.21/PL.00.07/2018) and Fundamental Research (PDU-No.641/ UN4.1/KEP/2019) of Hasanuddin University.

\section{Availability of data and materials}

Excel sheet format of the field dataset.

\section{Ethics approval and consent to participate}

Not applicable.

\section{Consent for publication}

Not applicable.

\section{Competing interests}

The authors declare that they have no competing interests.

\footnotetext{
Author details

1 Department of Geological Engineering, Hasanuddin University, JI. Poros Malino KM.6 Bontomarannu, Gowa, South Sulawesi 92171, Indonesia.

${ }^{2}$ Graduate School of International Resource Science, Akita University, 28-2,

Tegata-Ozawa, Akita 010-8502, Japan.
}

Received: 11 May 2019 Accepted: 18 December 2019

Published online: 30 December 2019

\section{References}

Bao H, Ampuero JP, Meng L, Fielding EJ, Liang C, Milliner SWD, Feng T, Huang $H$ (2019) Early and persistent supershear rupture of the 2018 magnitude 7.5 Palu earthquake. Nat Geosci 12:200-205. https://doi.org/10.1038/ s41561-018-0297-z

Bellier O, Beaudouin Th, Se'brier M, Villeneuve M, Bahar I, Putranto E, Pratomo I, Massault M, Seward D (1998) Active faulting in Central Sulawesi (Eastern Indonesia). In: Wilson P, Michel GW (eds) The geodynamics of S and SE Asia (GEODYSSEA) Project Final Report, EC contract CI1 ${ }^{*}$ CT93-0337 Scient Technical Rep STR 98-14:276-312

Bellier O, Se'brier M, Beaudouin Th, Villeneuve M, Braucher R, Bourles D, Siame L, Putranto E, Pratomo I (2001) High slip rate for a low seismicity along the Palu-Koro active fault in central Sulawesi (Indonesia). Terra Nova 13:463-470

Bellier O, Sebrier M, Seward D, Beaudouin T, Villeneuve M, Putranto E (2006) Fission track and fault kinematics analyses for new insight into the Late Cenozoic tectonic regime changes in West-Central Sulawesi (Indonesia). Tectonophysics 413:201-220

Bradley K, Mallick R, Andikagumi H, Hubbard J, Meilianda E, Switzer A, Du N, Brocard G, Alfian D, Benazir B, Feng G, Yun S-H, Majewski J, Wei S, Hill EM (2019) Earthquake-triggered 2018 Palu Valley landslides enabled by wet rice cultivation. Nat Geosci 12:935-939. https://doi.org/10.1038/s4156 1-019-0444-1

Cipta A, Robiana R, Griffin JD, Horspool N, Hidayati S, Cummings PR (2017) A probabilistic seismic hazard assessment for Sulawesi, Indonesia. In: Cummins PR, Meilano I (eds) Geohazards in Indonesia: earth science for disaster risk reduction, vol 441. Geological Society Special Publications, London, pp 133-152

Geospatial Information Authority of Japan (GSI) (2018) Orthoimages at part of Sulawesi Island area, taken on October 2018. http://www.gsi.go.jp/cais/ topic181005-index-e.html. Accessed 8 Jan 2019

Geotechnical Extreme Events Reconnaissance (GEER) (2019) Geotechnical Reconnaissance: the 28 September 2018 M7.5 Palu-Donggala, Indonesia Earthquake, Version 1.0; 3 April 2019

Go'mez JM, Madariaga R, Walpersdorf A, Chalard E (2000) The 1996 earthquakes in Sulawesi, Indonesia. Bull Seismol Soc Am 90(3):739-751

Hamilton W (1979) Tectonics of the Indonesian region. US Geological Survey Professional Paper, 1078, pp 1-345

National Center for Earthquake Studies (PuSGeN) (2017) Seismic source and hazard map of Indonesia 2017.http://litbang.pu.go.id/puskim/berita/ detail/1355/peta-sumber-dan-bahaya-gempa-indonesia-tahun-2017. Accessed 8 Jan 2019

Pelinovsky E, Yuliadi D, Prasetya G, Hidayat R (1997) The 1996 Sulawesi tsunami. Nat Hazards 16:29-38

Prasetya GS, de Lange WP, Healy TR (2001) The Makassar Strait tsunamigenic region, Indonesia. Nat Hazards 24:295-307

Ratman N (1976) Geological map of the Tolitoli quadrangle, North Sulawesi, Scale 1:250 000 (Quadrangles 2016-2117-2117). Geological Survey of Indonesia

Silver EA, McCaffrey R, Smith RB (1983) Collision, rotation, and the initiation of subduction in the evolution of Sulawesi Indonesia. J Geophys Res 88:9407-9418

Simandjuntak TO, Surono, Supandjono JB (1991) The geology of the Poso quadrangle, Sulawesi (Quadrangle 2114), Scale 1:250 000. Geological Research and Development Centre, Bandung

Socquet A, Vigny C, Chamot-Rooke N, Simons W, Rangin C, Ambrosius B (2006) India and Sunda plates motion and deformation along their boundary in Myanmar determined by GPS. J Geophys Res 111:1-15. https://doi. org/10.1029/2005JB003877

Socquet A, Hollingsworth J, Pathier E, Bouchon M (2019) Evidence of supershear during the 2018 magnitude 7.5 Palu earthquake from space geodesy. Nat Geosci 12:192-199. https://doi.org/10.1038/s41561-018-0296-0

Sukamto R (1973) Reconnaissance Geologic Map of Palu Area, Sulawesiscale 1:250 000. Geological Survey of Indonesia, Directorate of Mineral Resources (Quadrangles 2015-2115). Geological Research and Development Centre, Bandung

Sukido D, Sukarna, Sutisna K (1993) Geological Map of the Pasangkayu Quadrangle, Sulawesi-scale 1:250 000 Geological Survey of Indonesia, Directorate of Mineral Resources (Quadrangles 2014). Geological Research and Development Centre, Bandung 
Tjia HD (1981) Example of young tectonism in Eastern Indonesia. In: Barber AJ, Wiryosudjono S (eds) The geology and tectonics of Eastern Indonesia. Spec Publ Geol Res and Dev Centre, Bandung, vol 2, pp 89-104

USGS (2018) https://www.usgs.gov/news/magnitude-75-earthquake-nearpalu-indonesia. Accessed 8 Jan 2019

Walpersdorf A, Rangin C, Vigny C (1998a) GPS compared to longterm geologic motion of the northern arm of Sulawesi. Earth Planet Sci Lett 159:47-55

Walpersdorf A, Vigny C, Subarya C, Manurung P (1998b) Monitoring of the Palu-Koro fault (Sulawesi) by GPS. Geophys Res Lett 25:2313-2316

Watkinson IM (2011) Ductile flow in the Metamorphic Rocks of Central Sulawesi. In: Hall R, Cottam MA, Wilson MEJ (eds) The SE Asian Gateway: history and tectonics of the Australia-Asia Collision, vol 355. Geological Society of London Special Publications, London, pp 157-176

Watkinson IM, Hall R (2017) Fault systems of the eastern Indonesian triple junction: evaluation of Quaternary activity and implications for seismic hazards. In: Cummins PR, Meilano I (eds) Geohazards in Indonesia: earth science for disaster risk reduction. Geological Society of London Special Publications 441(1):71-120

Watkinson IA, Hall R (2019) Impact of communal irrigation on the 2018 Palu earthquake-triggered landslides. Nat Geosci 12:940-945. https://doi. org/10.1038/s41561-019-0448-x

Wells DL, Coppersmith KJ (1994) New empirical relationships among magnitude, rupture length, rupture area, and surface displacement. Bull Seismo Soc Am 84:974-1002

Zhang Y, Cheng YT, Feng W (2019) Complex multiple-segment ruptures of the 28 September 2018, Sulawesi, Indonesia, earthquake. Sci Bull 64:650-652

\section{Publisher's Note}

Springer Nature remains neutral with regard to jurisdictional claims in published maps and institutional affiliations.

\section{Submit your manuscript to a SpringerOpen ${ }^{\circ}$ journal and benefit from:}

- Convenient online submission

- Rigorous peer review

- Open access: articles freely available online

- High visibility within the field

- Retaining the copyright to your article

Submit your next manuscript at $\boldsymbol{\text { springeropen.com }}$ 